\title{
Barium Hydroxide Octahydrate $\left(\mathrm{Ba}(\mathrm{OH})_{2} \cdot 8 \mathrm{H}_{2} \mathrm{O}\right)$ as a Substitute Alternative for Barium Carbonate $\left(\mathrm{BaCO}_{3}\right)$ in Synthesis Superconductor of $\mathrm{Nd}_{1} \mathrm{Ba}_{2} \mathrm{Cu}_{3} \mathrm{O}_{7-\delta}$ Phase
}

\author{
M. Sumadiyasa, I. B. S. Manuaba, P. Suardana \\ Department of Physics, Faculty of Mathematics and Natural Sciences, Udayana University, Badung, Bali, Indonesia \\ Email: sumadiyasa@unud.ac.id
}

How to cite this paper: Sumadiyasa, M., Manuaba, I.B.S. and Suardana, P. (2018) Barium Hydroxide Octahydrate $\left(\mathrm{Ba}(\mathrm{OH})_{2} \cdot 8 \mathrm{H}_{2} \mathrm{O}\right)$ as a Substitute Alternative for Barium Carbonate $\left(\mathrm{BaCO}_{3}\right)$ in Synthesis Superconductor of $\mathrm{Nd}_{1} \mathrm{Ba}_{2} \mathrm{Cu}_{3} \mathrm{O}_{7-\delta}$ Phase. Journal of Materials Science and Chemical Engineering, 6, 117-124.

https://doi.org/10.4236/msce.2018.67013

Received: June 3, 2018

Accepted: July 15, 2018

Published: July 18, 2018

Copyright (C) 2018 by authors and Scientific Research Publishing Inc. This work is licensed under the Creative Commons Attribution International License (CC BY 4.0).

http://creativecommons.org/licenses/by/4.0/

\begin{abstract}
One of the basic ingredients in conventional preparation of cuprates-based superconducting materials such as the $\mathrm{Nd}-\mathrm{Ba}-\mathrm{Cu}-\mathrm{O}$ superconducting system, especially the $\mathrm{Nd}_{1} \mathrm{Ba}_{2} \mathrm{Cu}_{3} \mathrm{O}_{7-\delta}$ phase is Barium Carbonate $\left(\mathrm{BaCO}_{3}\right)$. It has the potential to produce the carbon dioxide $\left(\mathrm{CO}_{2}\right)$ air pollutant. Therefore it is necessary to look for other materials as the source of $\mathrm{Ba}$ atom which does not produce $\mathrm{CO}_{2}$ gas. In this research has been successfully made the $\mathrm{Nd}_{1} \mathrm{Ba}_{2} \mathrm{Cu}_{3} \mathrm{O}_{7-\delta}$ phase with the Barium Hydroxide Octahydrate $\left(\mathrm{Ba}(\mathrm{OH})_{2} \cdot 8 \mathrm{H}_{2} \mathrm{O}\right)$ as a source of $\mathrm{Ba}$ atom. The results of the characterization XRD has been shown the main peaks of the $\mathrm{Nd}_{1} \mathrm{Ba}_{2} \mathrm{Cu}_{3} \mathrm{O}_{7-\delta}$ phase. Refinement of the XRD data by using Rietica software, obtained the value of GofF (Goodness of Fit) $=1.7023$ and lattice parameter $\mathrm{a} \approx \mathrm{b}<\mathrm{c} / 3$ with a value of $\mathrm{c} / 3=3.9275 \AA$.
\end{abstract}

\section{Keywords}

$\mathrm{Nd}_{1} \mathrm{Ba}_{2} \mathrm{Cu}_{3} \mathrm{O}_{7-\delta}$ Phase, $\mathrm{Ba}$ Atom, Barium Carbonate, Barium Hydroxide Octahydrate, GofF

\section{Introduction}

One of the high Tc superconducting cupric materials is the superconductor of $\mathrm{Nd}_{1} \mathrm{Ba}_{2} \mathrm{Cu}_{3} \mathrm{O}_{7-\delta}$ phase, it is Tc exceeds to the boiling point of liquid nitrogen (77 K) [1] [2]. It is widely studied because of it is high Tc and simple crystal lattice structures, and also it can operate with high Jc in a fairly high magnetic field at $77 \mathrm{~K}$ [3] [4] [5]. Therefore it can be one of the candidates of superconductor materials that can be applied in the field of industry.

There are two standard methods used to create high Tc superconductors, 
namely solid-state reaction method and coprecipitation method [6]. The first method usually uses Barium Carbonate $\left(\mathrm{BaCO}_{3}\right)$ while the second method uses $\mathrm{Ba}\left(\mathrm{NO}_{2}\right)_{3}$ as a source of $\mathrm{Ba}$ atom. Similarly, in the preparation of the $\mathrm{Nd}_{1} \mathrm{Ba}_{2} \mathrm{Cu}_{3} \mathrm{O}_{7-\delta}$ phase typically uses a solid reaction method with $\mathrm{Nd}_{2} \mathrm{O}_{2}, \mathrm{BaCO}_{3}$ and $\mathrm{CuO}$ powders as the starting material [3] [4] [7]. With these starting materials it potentially produces air pollutant compounds in the form of $\mathrm{CO}_{2}$ gas, as indicated by the chemical reaction in Equation (1).

$$
\mathrm{Nd}_{2} \mathrm{O}_{3}+4 \mathrm{BaCO}_{3}+6 \mathrm{CuO} \rightarrow 2 \mathrm{Nd}_{1} \mathrm{Ba}_{2} \mathrm{Cu}_{3} \mathrm{O}_{6.5}+4 \mathrm{CO}_{2}
$$

It is necessary to think about how to make superconducting material by the simple methods, non-toxic and does not produce air pollutants. In this research, the superconducting materials have been made by using Barium Hydroxide Octahydrate $\left(\mathrm{Ba}(\mathrm{OH})_{2} \cdot 8 \mathrm{H}_{2} \mathrm{O}\right)$ as a source of $\mathrm{Ba}$, as indicated by the chemical reaction in Equation (2).

$$
\mathrm{Nd}_{2} \mathrm{O}_{3}+4 \mathrm{Ba}(\mathrm{OH})_{2} \cdot 8 \mathrm{H}_{2} \mathrm{O}+6 \mathrm{CuO} \rightarrow 2 \mathrm{Nd}_{1} \mathrm{Ba}_{2} \mathrm{Cu}_{3} \mathrm{O}_{6.5}+36 \mathrm{H}_{2} \mathrm{O}
$$

It appears that it does not produce $\mathrm{CO}_{2}$ gas, but it produces water vapor.

In this work the author describes the use of $\mathrm{Ba}(\mathrm{OH})_{2} \cdot 8 \mathrm{H}_{2} \mathrm{O}$ as a substitute of $\mathrm{BaCO}_{3}$ in synthesizing the $\mathrm{Nd}_{1} \mathrm{Ba}_{2} \mathrm{Cu}_{3} \mathrm{O}_{7-\delta}$ phase. The synthesis results are characterized by XRD. From XRD the existence of the $\mathrm{Nd}_{1} \mathrm{Ba}_{2} \mathrm{Cu}_{3} \mathrm{O}_{7-\delta}$ phase is established with Match-3.6.1 software, and the lattice parameter of the $\mathrm{Nd}_{1} \mathrm{Ba}_{2} \mathrm{Cu}_{3} \mathrm{O}_{7-\delta}$ is determined by using Rietica software.

\section{Research Methods}

In this study $\mathrm{Nd}_{1} \mathrm{Ba}_{2} \mathrm{Cu}_{3} \mathrm{Oy}$ samples were prepared by using solid-state reaction method with starting material in powder form. The first sample is made with the reagent grade chemicals of high purity (Aldrih 99.99\%) $\mathrm{Nd}_{2} \mathrm{O}_{3}, \mathrm{CuO}$ and $\mathrm{Ba}(\mathrm{OH})_{2} \cdot 8 \mathrm{H}_{2} \mathrm{O}$ powders were used as the raw materials, while the second sample is made with the starting material $\mathrm{BaCO}_{3}$ as a comparison sample. In this research the wet mixing method is used to increase sample mixture homogeneity as conducted in a reference [8]. The starting materials of powder and alcohol are mixed with a magnetic stirrer for 4 hours, then it is heated at temperature of $200^{\circ} \mathrm{C}$ until a crust shaped sample is obtained. The crust shaped sample was cooled to room temperature, and after it being crushed in the mortar then it was calcinated at $900^{\circ} \mathrm{C}$ for 12 hours. The calcination product is then made in form a pellet, and finally sintered at a temperature of $910^{\circ} \mathrm{C}$ for 15 hours in an air environment within the furnace.

The phase analysis of the sample was performed with an X-ray Diffraction (XRD). The XRD characterization results were analyzed by Rietica software. The model of the cell unit structure is conducted by using the Diamon 4.1 software.

\section{Result and Discussion}

\subsection{Refinement Result}

Figure 1 shows the XRD pattern of the sample that is prepared with $\mathrm{BaCO}_{3}$ 


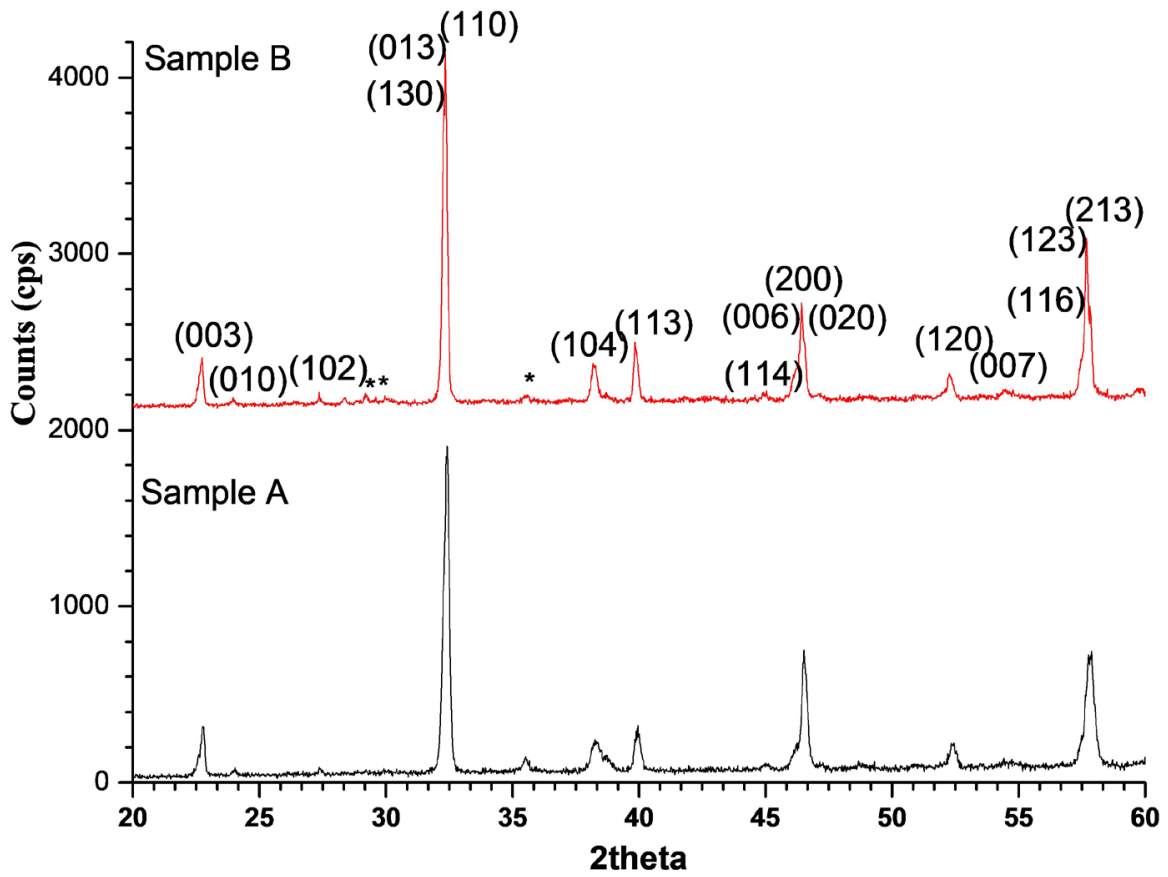

Figure 1. The XRD patterns of: (A) the sample was synthesized with $\mathrm{BaCO}_{3}$ and (B) the sample was synthesized with $\mathrm{Ba}(\mathrm{OH})_{2} \cdot 8 \mathrm{H}_{2} \mathrm{O} .{ }^{*}=$ the impurities.

(marked by A) and $\mathrm{Ba}(\mathrm{OH})_{2} \cdot 8 \mathrm{H}_{2} \mathrm{O}$ (marked by $\mathrm{B}$ ) respectively. At intervals of $20^{\circ}-60^{\circ}$, it appears that both spectra show the same pattern of diffraction spectra. Figure 1 has been shown the major peaks of the $\mathrm{Nd}_{1} \mathrm{Ba}_{2} \mathrm{Cu}_{3} \mathrm{O}_{7-\delta}$ phase, i.e. the peaks of the diffraction plane (013) and (103) are occurred at an angle of $2 \theta$ between $32^{\circ}-32.8^{\circ}$, the diffraction of planes (020) and (200) are occurred at an angle of $2 \theta$ between $46^{\circ}-47.3^{\circ}$, and the diffraction of planes (123) and (213) are occurred at an angle of $2 \theta$ between $57.5^{\circ}$ - 58.5 [3] [4] [9]. Search-match by using Match 3.6.1 software with entry number 96-154-0949 (formula $\mathrm{Nd}_{1} \mathrm{Ba}_{2} \mathrm{Cu}_{3} \mathrm{O}_{6.57}$ ) the volume fraction that of both sample are almost the same, i.e. $84 \%$ obtained. However, the diffraction peaks of sample B appear sharper and their intensity is higher than the same peaks in sample A. For example, peak of 103 at $2 \theta=32.36$, sample B have FWHM $=0.10$ and intensity $=1926$ counts, meanwhile same peak from sample A have FWHM $=0.16$ and intensity $=1854$ counts.

It has been conducted refinement to XRD data with Rietveld analysis method by using Rietica software with ICSD Collection Code 78453 as a reference, and was obtained data as shown in Table 1 and Table 2. From value of Goodness of Fit (GofF) as formulated in [10] and from Table 1 was obtained the GofF i.e. 1.8891 and 1.7023 respectively for sample A and sample B. The refinement result is said to be good if GofF < 2 [10] therefore, sample A and B have a good match between the experiment and the expected results. It appears to that sample B has a smaller GofF than sample A. Table 2 shows that the lattice parameter values of $a, b$ and $c$ for sample B are slightly larger than of sample A. It also appears that the equivalent to particle size of the sample $B$ is greater than of the sample A. It is indicates that the crystallization in the sample B is better than in the sample A. 
Table 1. The profile factor refinement results.

\begin{tabular}{cccc}
\hline Sample & $\mathrm{R}_{\mathrm{p}}$ & $\mathrm{R}_{\mathrm{wp}}$ & $\mathrm{R}_{\exp }$ \\
\hline $\mathrm{A}$ & 14.97 & 19.42 & 10.28 \\
$\mathrm{~B}$ & 14.95 & 18.81 & 11.05 \\
\hline
\end{tabular}

Table 2. The value of the lattice parameter of refinement results.

\begin{tabular}{cccccc}
\hline Sample & $a(\AA)$ & $b(\AA)$ & $c(\AA)$ & Cell Volume $\left(\AA^{3}\right)$ & $\begin{array}{c}\text { Equivalent to } \\
\text { particle size } \\
(\mathrm{nm})\end{array}$ \\
\hline A & $3.8952 \pm 0.0014$ & $3.9012 \pm 0.0005$ & $11.7617 \pm 0.0006$ & $178.7263 \pm 0.0416$ & $83.52 \pm 2.23$ \\
B & $3.9061 \pm 0.0005$ & $3.9076 \pm 0.0005$ & $11.7724 \pm 0.0008$ & $179.8382 \pm 0.0349$ & $115.02 \pm 2.73$ \\
\hline
\end{tabular}

Figure 2 shows the grouping of the peaks of the diffraction pattern based on the diffraction planes. The diffraction planes of (013) and (103), (006), (020) and (200), (123) and (213) are located at the $2 \theta$ angle intervals of $32.0^{\circ}-32.8^{\circ}, 45.7^{\circ}$ $47.0^{\circ}$, and $57.0^{\circ}-58.5^{\circ}$ respectively. The peaks of diffraction patterns on each diffraction plane are separated by the very small $2 \theta$ angle. These indirectly imply that the $\mathrm{Nd}_{1} \mathrm{Ba}_{2} \mathrm{Cu}_{3} \mathrm{O}_{7-\delta}$ phase formed on the samples $\mathrm{A}$ and $\mathrm{B}$ their structure are tends to in tetragonal symmetry [11] [12].

Figure 2 also shows there is the plane splitting and the $2 \theta$ angular shift toward a smaller $2 \theta$ angle on the XRD peaks pattern of sample $\mathrm{B}$, these indicate there to the difference of the lattice parameter value of $\mathrm{Nd}_{1} \mathrm{Ba}_{2} \mathrm{Cu}_{3} \mathrm{O}_{7-\delta}$ phase on the both samples as shown in Table 2. In this case the $c$-lattice parameter of sample $\mathrm{B}$ is greater than that of $\mathrm{A}$. As it is well known that the structure of the $\mathrm{Nd}_{1} \mathrm{Ba}_{2} \mathrm{Cu}_{3} \mathrm{O}_{7-\delta}$ phase can be in tetragonal or orthorhombic symmetry, it depends on the oxygen content. In the $\mathrm{Nd}_{1} \mathrm{Ba}_{2} \mathrm{Cu}_{3} \mathrm{O}_{7-\delta}$ lattice parameter $c$ depends on the oxygen content $y=7-\delta$ with $0 \leq \delta \leq 1$ [4] [7]. The linear relationship between the lattice parameters $c$ and the oxygen content for the $\mathrm{Nd}_{1} \mathrm{Ba}_{2} \mathrm{Cu}_{3} \mathrm{O}_{y}$ phase as in [13],

$$
c=(12.614-0.132 y) \AA
$$

It can be seen that the $c$-lattice parameter value is increase with the decreasing of oxygen content $y$. If the oxygen content is calculated by using equation (3) and from the lattice parameter $c$ in Table 2 was obtained the oxygen content of the samples $\mathrm{A}$ and $\mathrm{B}$ are $y=6.46$ and $y=6.38$ respectively. It was found that the $\mathrm{Nd}_{1} \mathrm{Ba}_{2} \mathrm{Cu}_{3} \mathrm{O}_{7-\delta}$ phase formed on samples $\mathrm{A}$ and $\mathrm{B}$ has different oxygen content with oxygen-deficient $\delta=0.54$ and $\delta=0.62$ respectively. The lattice parameters of $a, b$ and $c$ with $a \approx b<c / 3$ as shown in Table 2 , and the $c / 3$ value of samples A and $\mathrm{B}$ are $3.9206 \AA$ and $3.9275 \AA$ respectively. These conditions indicate that both samples are in the $\mathrm{Nd}_{1} \mathrm{Ba}_{2} \mathrm{Cu}_{3} \mathrm{O}_{7-\delta}$ phase formed on samples $\mathrm{A}$ and $\mathrm{B}$ has tetragonal symmetry [3] [14].

The orthorhombic splitting (OS) unit cell as in [9], i.e.

$$
O S=\frac{b-a}{a+b}
$$




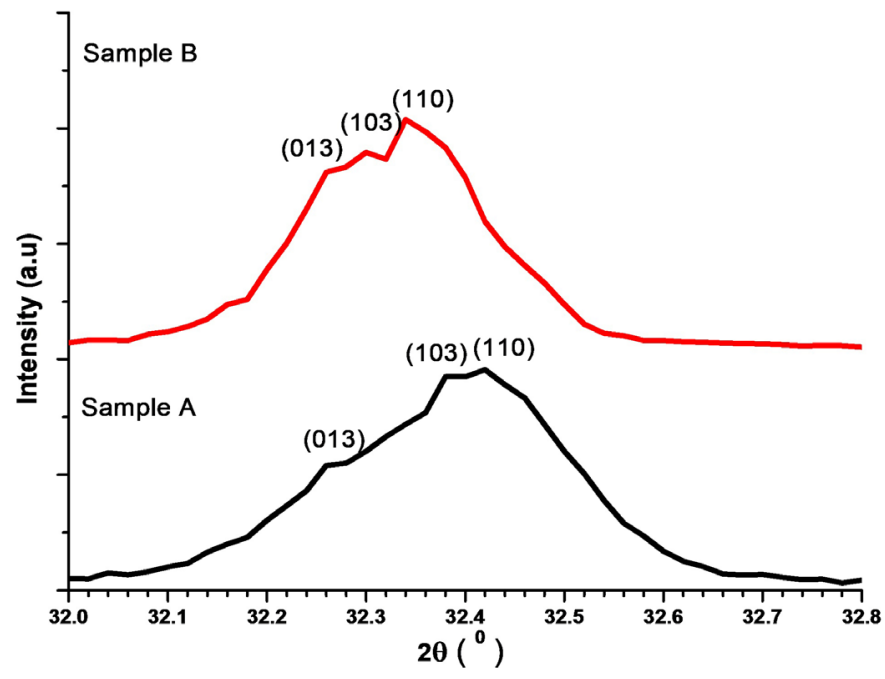

(A)

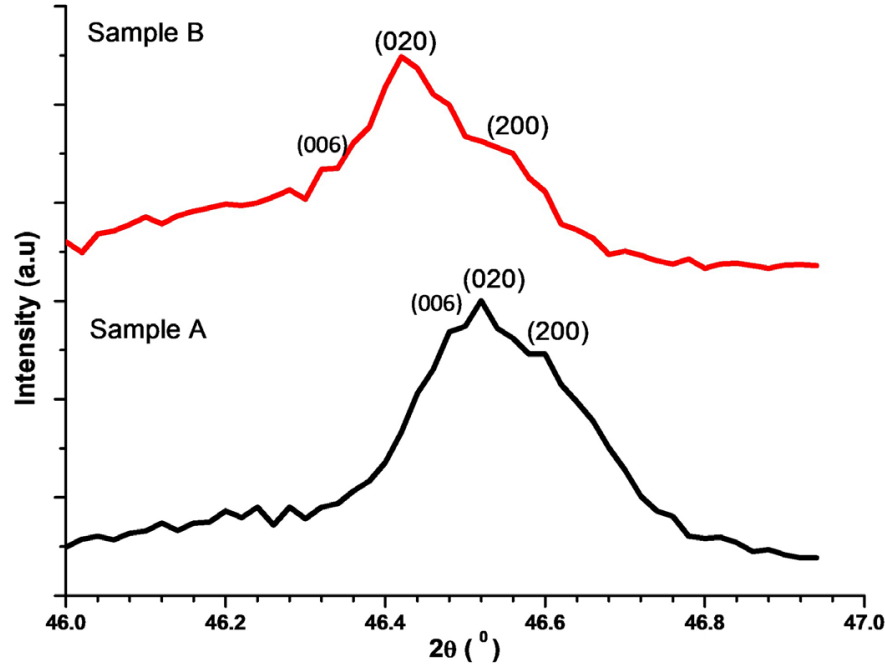

(B)

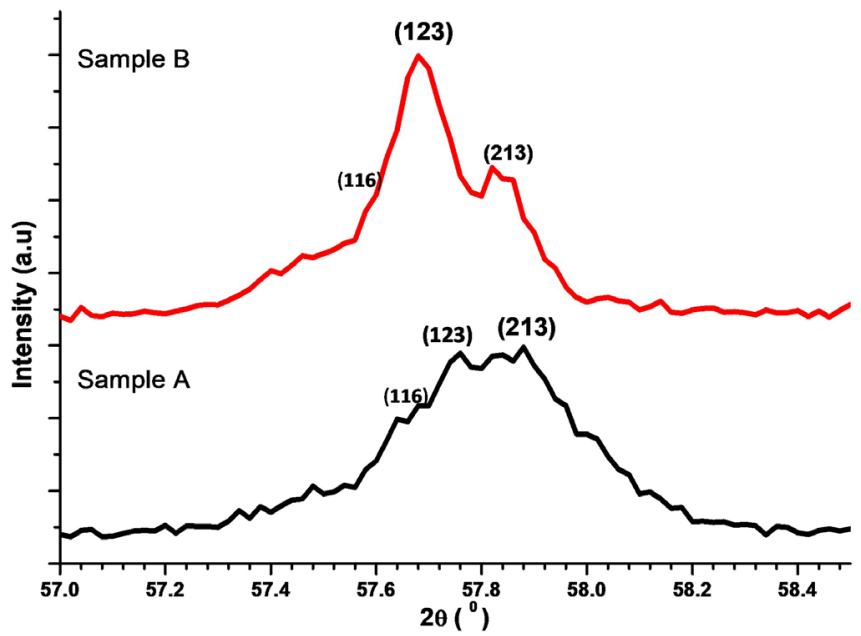

(C)

Figure 2. The main diffractions that showing the changes of the $\mathrm{Nd}_{1} \mathrm{Ba}_{2} \mathrm{Cu}_{3} \mathrm{O}_{7-\delta}$ cell lattice parameters: (013) and (103), (006), (020) and (200), (123) and (213). 
From Table 2, were obtained the value of OS $=7.7 \times 10^{-4}$ and $1.9 \times 10^{-4}$ for samples $A$ and sample $B$ respectively. It was found the value of OS is very small, that gives a hint that the $\mathrm{Nd}_{1} \mathrm{Ba}_{2} \mathrm{Cu}_{3} \mathrm{O}_{7-\delta}$ phase formed on sample $\mathrm{A}$ and $\mathrm{B}$ have a small that orthorhombicity.

Therefore, the symmetry of the $\mathrm{Nd}_{1} \mathrm{Ba}_{2} \mathrm{Cu}_{3} \mathrm{O}_{7-\delta}$ phase on both the sample are tends to be tetragonal. This corresponds to the amount of which oxygen content in the cell unit less that than to 6.55, oxygen-deficient $\delta>0.45$ [2] [7].

\subsection{Lattice Structure Model}

It has been made a model of the lattice structure (cell unit) for both samples by using Diamon 4.4.0 software and the refinement result, it is shown in Figure 3. The legend of the Figure 3 corresponds to the legend of the figure that has made as in [14]. It was found that the structure of the $\mathrm{Nd}_{1} \mathrm{Ba}_{2} \mathrm{Cu}_{3} \mathrm{O}_{7-\delta}$ phase that formed on the sample $\mathrm{A}$ and $\mathrm{B}$ are similar.

The structure of $\mathrm{Nd}_{1} \mathrm{Ba}_{2} \mathrm{Cu}_{3} \mathrm{O}_{7-\delta}$ that has been produced in this study are agree to the structure of $\mathrm{Y}_{1} \mathrm{Ba}_{2} \mathrm{Cu}_{3} \mathrm{O}_{7-\delta}$ [15] [16]. The crystal structure is characterized by the arrangement of copper-oxygen planes and copper-oxygen chains: $\mathrm{CuO}$ layer where in the a-c plane, $\mathrm{Cu}(1)$ copper is surrounded by four oxygen ions $\left(\mathrm{CuO}_{4}\right)$ and it forms a chain along the b-axis. Two layers of $\mathrm{CuO}_{2}$ where the $\mathrm{Cu}(2)$ is surrounded by five oxygen ions, it forms a polyhedron. Both layers of $\mathrm{CuO}_{2}$ are separated by an $\mathrm{Nd}$ atom.

Figure 3 shows that $\mathrm{Ba}$ atom was positioned above and below of the cell unit, while the position of an $\mathrm{Nd}$ atom is at it's a center. $\mathrm{Nd}$ and $\mathrm{Ba}$ atom are piled along the $\mathrm{c}$-axis in the sequence of $\mathrm{Ba}-\mathrm{Nd}-\mathrm{Ba}$. The position of $\mathrm{Nd}$ atom is lies between of the two $\mathrm{CuO}_{2}$ plane and the $\mathrm{Ba}$ atom lies between $\mathrm{CuO}_{2}$ planes and
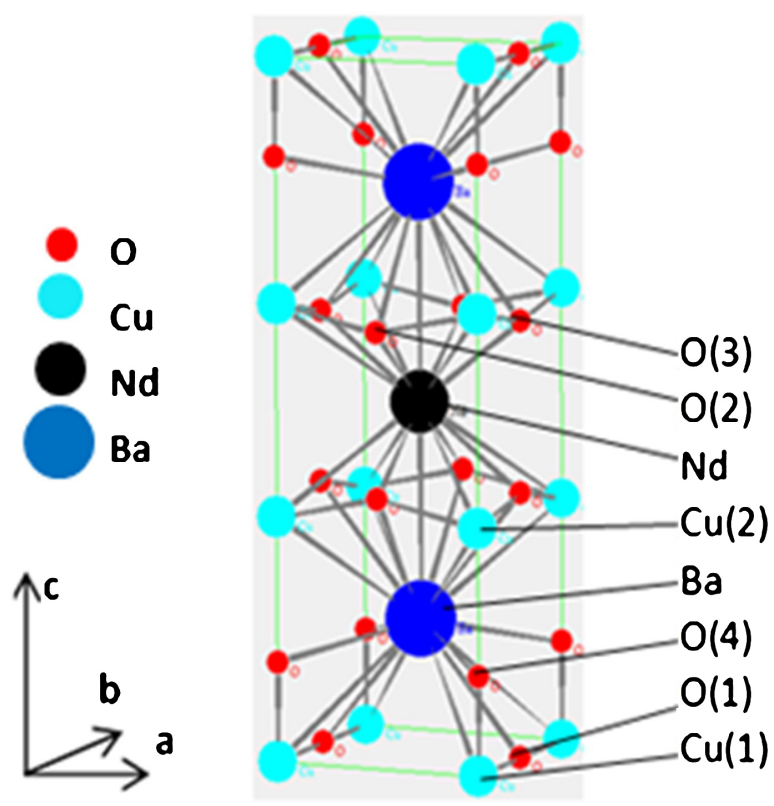

(A)

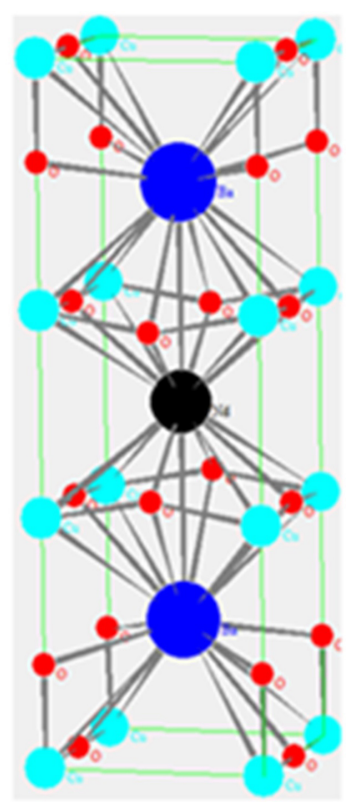

(B)

Figure 3. The Cell Unit Model of: (A) Sample A; (B) Sample B. 
$\mathrm{CuO}_{4}$ chains. In the layered structure, the stacking sequence of layers along the $\mathrm{c}$-axis of the cell unit as follows $\mathrm{BaO}-\mathrm{CuO}-\mathrm{BaO}-\mathrm{CuO}_{2}-\mathrm{Nd}-\mathrm{CuO}_{2}-\mathrm{BaO}-\mathrm{CuO}-\mathrm{BaO}$ [17].

\section{Summary}

The superconductors of the $\mathrm{Nd}_{1} \mathrm{Ba}_{2} \mathrm{Cu}_{3} \mathrm{O}_{7-\delta}$ phase can be well synthesized by using $\mathrm{Ba}(\mathrm{OH})_{2} \cdot 8 \mathrm{H}_{2} \mathrm{O}$ as a source of $\mathrm{Ba}$ atom, it is indicated by the GofF value of 1.7023. The difference of the lattice parameters $a$ and $b$ is very small so that the orthorhombicity is very small, therefore the unit cell of the $\mathrm{Nd}_{1} \mathrm{Ba}_{2} \mathrm{Cu}_{3} \mathrm{O}_{7-\delta}$ tends to be in tetragonal symmetry. The calculation of oxygen content yields 6.38 . Thus it can be concluded that the $\mathrm{Nd}_{1} \mathrm{Ba}_{2} \mathrm{Cu}_{3} \mathrm{O}_{7-\delta}$ phase formed tends to be tetragonal phase. Therefore, it is suggested that for synthesizing of the $\mathrm{Nd}_{1} \mathrm{Ba}_{2} \mathrm{Cu}_{3} \mathrm{O}_{7-\delta}$ phase by using $\mathrm{Ba}(\mathrm{OH})_{2} \cdot 8 \mathrm{H}_{2} \mathrm{O}$ as a source of $\mathrm{Ba}$ atom is carried out in the oxygen atmosphere.

\section{Acknowledgements}

This research was supported by the Fundamental Research scheme of the RISTEKDIKTI. The authors are thankful to RISTEKDIKTI and LPPM of Udayana University.

\section{References}

[1] Xiao, G., Streitz, F.H., Gavrin, A. and Chien, C.L., (1987) Magnetic Characteristics of Superconducting $\mathrm{RBa}_{2} \mathrm{Cu}_{3} \mathrm{O}_{7-\delta}(\mathrm{R}=\mathrm{Nd}, \mathrm{Sm}, \mathrm{Eu}, \mathrm{Gd}, \mathrm{Dy}, \mathrm{Ho}, \mathrm{El}$ ', Tm and $\mathrm{Yb})$. Solid State Communications, 63, 817-820. https://doi.org/10.1016/0038-1098(87)90892-1

[2] Wong-Ng, W., Cook, L.P., Su, H.B., Vaudin, M.D., Chiang, C.K., Welch, D.R., Fuller, E.R., Yang Jr., Z. and Bennett, L.H. (2006) Phase Transformations in the High-Tc Superconducting Compounds, $\mathrm{Ba}_{2} \mathrm{RCu}_{3} \mathrm{O}_{7-\delta}(\mathrm{R}=\mathrm{Nd}, \mathrm{Sm}, \mathrm{Gd}, \mathrm{Y}, \mathrm{Ho}$, and Er). Journal of Research of the National Institute of Standards and Technology, 111, 41-55. https://doi.org/10.6028/jres.111.004

[3] Muralidhar, M., Sakai, N., Jirsa, M. and Murakami, M. (2002) Fabrication and Characterization of $\mathrm{LRE}_{1+\mathrm{x}} \mathrm{Ba}_{2-\mathrm{x}} \mathrm{CuO}_{3 \mathrm{y}}$ (LRE: Nd, Eu, Gd, NEG) Superconductors: A Low Oxygen Partial Pressure. Physica C, 378-381, 646-650. https://doi.org/10.1016/S0921-4534(02)01513-7

[4] Chausan, H.S. and Murakami, M. (1998) Temperature-Controlled Tailoring of $J_{c}-$ B Properties in the Nd-Ba-Cu-O System, Applied Superconductivityide Superconductor Applied Superconductivity, 6, 169-174. https://doi.org/10.1016/S0964-1807(98)00098-2

[5] Cardwell, D. (2016) Bulk (RE)bco Superconductors. Science. Technology and Applications, ESAS Summer School, Bologna, 8-14.

[6] Chen, X.D., Lee, S.Y., Golben, J.P., Lee, S.I., McMichael, R.D., Song, Y., Noh, T.W. and Gaines, J.R. (1987) Pratical Preparation of Copper Oxide Superconductor. Review of Scientific Instruments, 58, 1565-1571. https://doi.org/10.1063/1.1139402

[7] Shaked, H., Veal, B.W., Faber Jr., J., Hiterman, R.L., Balachandran, U., Tomlins, G., Shi, H., Mors, L. and Paulikas, A.P. (1990) Structural and Superconducting Properties of Oxygen-Deficient $\mathrm{NdBa}_{2} \mathrm{Cu}_{3} \mathrm{O}_{7-\delta}$. Physical Review B, 41, 4173-4180. 
https://doi.org/10.1103/PhysRevB.41.4173

[8] Sumadiyasa, M., Adnyana, I.G.A.P., Wendri, N. and Suardana, P. (2017) Synthesis and Characterization of GLBCO-123 Phase: $\mathrm{Gd}_{1-\mathrm{x}} \mathrm{L}_{\mathrm{x}} \mathrm{Ba}_{2} \mathrm{Cu}_{3} \mathrm{O}_{7-\delta}(\mathrm{x}=0.0-0.5)$, Journal of Materials Scienceand Chemical Engineering, 5, 49-57. https://doi.org/10.4236/msce.2017.511005

[9] Yossefov, P., Shter, G.E., Reisner, G.M., Friedman, A., Yeshurun and Grader, G.S. (1997) Relationship of Solubility Parameter (x), Powder Properties and Phase Formation in the $\mathrm{Nd}_{1 \div \mathrm{x}} \mathrm{Ba}_{2-\mathrm{x}} \mathrm{Cu}_{3} \mathrm{O}_{6.5 \div \mathrm{x} / 2 \div 8}$ System, Physica $C, 275,299-310$. https://doi.org/10.1016/S0921-4534(96)00725-3

[10] Lutterotti, L. (2006) Introduction to Diffraction and the Rietveld Method. Laboratorio Scienza Tecnologiadei Materiali, Corso.

[11] Kini, A.M., Geiser, U., Kao, H.-C.I., Douglas Carlson, K., Wang, H.H., Monaghan, M.R. and Williams, J.M. (1987) High-T, Superconductors: Selective Preparation and Characterization of Tetragonal and Orthorhombic (93 K Superconductor) Phases of $\mathrm{YBa}_{2} \mathrm{Cu}_{3} \mathrm{O}_{7-\delta}$ Inorganic Chemistry, 26, 1836-1637.

https://doi.org/10.1021/ic00259a004

[12] Howe, B.A. (2014) Crystal Structure and Superconductivity of $\mathrm{YBa}_{2} \mathrm{Cu}_{3} \mathrm{O}_{7-\mathrm{x}}$. Ph.D. Thesis, Minnesota State University, Mankato Mankato, Minnesota.

[13] Tang, W.H. and Gao, J. (1999) Preparation and Characterization of $\mathrm{NdBa}_{2} \mathrm{Cu}_{3} \mathrm{O}_{\mathrm{y}}$ Thin Films. IEEE Transactions on Applied Superconductivity, 9, 590-593. https://doi.org/10.1109/77.784700

[14] Chen, I-W., Keating, S.J., Keating, C.Y., Wu, X.W., Xu, J., Reyes-Morel, P.E. and Tien, T.Y. (1987) Structural Behavior and Superconductivity of $\mathrm{YBa}_{2} \mathrm{Cu}_{3} \mathrm{O}_{\mathrm{x}}$. Solid State Communications, 63, 997-1001. https://doi.org/10.1016/0038-1098(87)90648-X

[15] Rahman, Md.A., Rahaman, Md.Z. and Samsuddoha, Md.N. (2015) A Review on Cuprate Based Superconducting Materials Including Characteristics and Applications. American Journal of Physics and Applications, 3, 39-56. https://doi.org/10.11648/j.ajpa.20150302.15

[16] Kim, S.I. (2007) The Critical Current Density of $\mathrm{YBa}_{2} \mathrm{Cu}_{3} \mathrm{O}_{7-\mathrm{x}}$ Coated Conductors. Ph.D. Thesis, University of Wisconsin, Madiso.

[17] Hott, R. (2014) High Temperature Superconductivity 1. In: Narlikar, A.V., Ed., Materials: Materials Aspects of High-Temperature Superconductors for Applications, Springer, Berlin, 1-28. 